\section{Scientific journal}

\section{PHYSICAL AND MATHEMATICAL EDUCATION}

Has been issued since 2013.

Науковий журнал

ФІЗИКО-МАТЕМАТИЧНА ОСВІТА

Видається з 2013.
ISSN 2413-158X (online)

ISSN 2413-1571 (print)

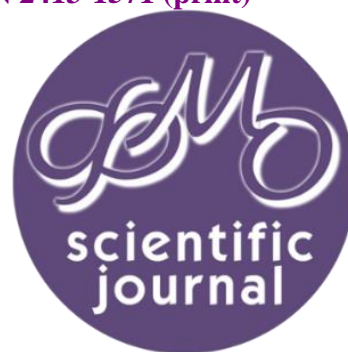

Грицюк О.С., Черненко В.П., Максимова Л.П. Едьютейнмент на уроках інформатики: досвід впровадження у з3СО Кременчука. Фізико-математична освіта. 2021. Випуск 4(30). С. 40-45.

Hrytsiuk O., Chernenko V., Maksymova L. Edutainment in computer science lessons: experience of implementation in Kremenchuk schools. Physical and Mathematical Education. 2021. Issue 4(30). P. 40-45.

DOI 10.31110/2413-1571-2021-030-4-006

удк 378.14.015.62

О.С. Грицюк

Кременчуцький національний університет імені Михайла Остроградського, Україна hrytsiuk.elena@gmail.com ORCID: https://orcid.org/0000-0003-2117-626X

В.П. Черненко Кременчуцький національний університет імені Михайла Остроградського, Україна varvara.chernenko@ukr.net ORCID: https://orcid.org/0000-0002-2728-6876

л.П. Максимова Кременчуцький національний університет імені Михайла Остроградського, Україна Ipmax@ukr.net

ORCID: https://orcid.org/0000-0001-7197-3254

\title{
ЕДЬЮТЕЙНМЕНТ НА УРОКАХ ІНФОРМАТИКИ: ДОСВІД ВПРОВАДЖЕННЯ У ЗЗСО КРЕМЕНЧУКА
}

АНОТАЦІЯ

Формулювання проблеми. У статті узагальнюються результати дослідження стану впровадження едьютейнменту, тобто навчання через гру, у закладах загальної середньої освіти Кременчука. Метою дослідження $\epsilon$ аналіз досвіду впровадження форм едьютейнменту на уроках інформатики у закладах загальної середньої освіти Кременчука.

матеріали і методи. Для розв'язання поставлених завдань та досягнення мети дослідження використано комплекс методів, серед яких основними є опитування (для виявлення форм едьютейнменту, які використовуються вчителями інформатики 33СО Кременчука), компаративний (для порівняння поширення ігрових практик у різних школах), а також методи математичної статистики (для кількісного та якісного аналізу емпіричних даних). Обраний методологічний інструментарій дозволив дослідити стан впровадження едьютейнменту на уроках інформатики у з3СО Кременчука.

Результати. Аналіз результатів дослідження засвідчив, що переважна більшість учителів кременчуцьких з3сО ознайомлені з ігровими практиками навчання та вважають їх корисними для організації уроків інформатики. Водночас опитування показало, що у більшості закладів освіти існують певні обмеження використання конкретних форм едьютейнменту: якщо візуалізація навчального матеріалу використовується у всіх школах, то змагальні форми навчання і особливо вебквести потребують уваги вчителів інформатики. На основі результатів емпіричного дослідження було розроблено низку рекомендацій щодо впровадження ігрових практик у навчання інформатики у кременчуцьких $33 С 0$.

Висновки. У дослідженні доводиться доцільність ширшого запровадження вебквесту як інструменту підвищення пізнавальної активності учнів, а також їхної мотивації вивчення інформатики. Імплементація едьютейнменту у навчання інформатики здатна значно підвищити пізнавальну активність та мотивацію учнів до вивчення предмету. Крім того, ігрові практики сприятимуть зменшенню психологічної напруженості.

КЛЮчОвІ СлОвА: едьютейнмент, ігрові практики навчання, інформатика, заклади загальної середньої освіти Кременчука, візуалізація навчального матеріалу, змагання, вебквест.

\section{ВСТУП}

Едьютейнмент, тобто ігрова педагогіка, впровадження ігрових практик у навчання сьогодні набуває значної популярності як за рубежем (див., наприклад, роботи 3. Окана (Okan, 2003), Н. Аксакал (Aksakal, 2015), Дж. Немець та Дж. Трна (Němec, Trna, 2007), М. С. Зідик та Л. Уоллес (Zeedyk, Wallace, 2003), так і в Україні (Крутій, 2017). Гейміфікація навчання і становлення едьютейнменту сприяють зниженню негативних наслідків діджиталізації, інформаційного впливу, перевантаження інформацією. 
Типологічною ознакою сьогоденної шкільної освіти розвитку є їі швидкий перехід у різноманітні мережеві форми навчання. Події останніх двох років (мається на увазі пандемія) пришвидшили впровадження дистанційної освіти, яка передбачає отримання знань в мережі Інтернет. Негативними наслідками цих тенденцій $є$ втрата дитиною контролю над інформацією через ї̈ необмежену доступність, що може викликати негативний психологічний вплив і деструктивну поведінку.

Споконвіку гра є одним з перевірених інструментів уникнення цих небезпечних явищ. Вона має велике значення для розвитку особистості і ефективна для навчання, розвитку та виховання. Гра має пряме відношення до всіх інших видів діяльності - пізнання, праці, культури, спілкування.

Узагальнення і поширення передового ігрового досвіду, ознайомлення з новими ігровими технологіями, створення цікавого і безпечного освітнього середовища, яке сприяє конструктивному розвитку школярів $є$ важливим завданням сучасної української освіти. Едьютейнмент дозволяє знизити напругу в соціокультурному розвитку учнів, навчити їх навичкам конструктивного спілкування, зберегти культуру цього спілкування. Ігрові практики умикають мимовільну увагу, яка сприяє більш точному сприйняттю і кращому запам'ятовуванню навчального матеріалу.

У основу едьютейнменту покладено такі базові педагогічні принципи:

- принцип поєднання теорії з практикою, оскільки гармонійне навчання і виховання випливає з життя і нерозривно з ним пов'язані як через джерело знань, так і через результат навчання;

- принцип послідовності, оскільки учень лише тоді здатний набути знань і навичок, коли володіє системою чітко взаємопов'язаних понять, послідовність яких зумовлена логікою побудови навчального матеріалу і когнітивними можливостями учнів;

- принцип доступності, тому що доступність навчання визначається віковими та індивідуальними особливостями учнів, організацією навчального процесу, застосовуваними методами навчання та ін.

Дослідники вважають, що едьютейнмент увібрав в себе найкраще з таких областей знання, як:

педагогіка (наприклад, педагогічні принципи); психологія (комунікативні теорії); інформатика (сучасні інформаційні та комунікаційні технологіï) (Němec, Trna, 2007). Едьютейнмент пропонують розглядати широко: адже це такий тип навчання, який пов'язаний не тільки з розважальним механізмом, а й з іншими процесами (Corona, Perrotta, Polcini, Cozzarelli, 2011). Едьютейнмент виступає у ролі допоміжного засобу, а розвага є швидше лише першою стадією використання едьютейнменту. Адже кінцева мета процесу навчання - стійкий інтерес до навчання, захопленість предметом (Aksakal, 2015).

Інформатика як навчальний предмет шкільної освіти, виникнення якого зумовлено саме становленням інформаційного суспільства, на нашу думку, найбільш потребує впровадження форм едьютейнменту, адже сучасна дитина, яка проводить за екраном монітора чи іншими гаджетами левову частку часу, саме на уроках інформатики має навчатися правилам поведінки з інформацією з мережі. І краще це робити в ігровій формі, оскільки вона $є$ ефективнішою і доступнішою для учнів, що зазначають, зокрема, зарубіжні вчені, які наполягають на зв'язку інформаційних технологій та едьютейнменту (див., наприклад ґрунтовне дослідження колективу італійських вчених (Corona, Cozzarelli, Palumbo, Sibilio, 2013)). У зв'язку з комп'ютеризацією суспільства власне комп'ютер стає основним технічним засобом у навчанні, а зміст навчання поступово трансформується у цифровий контент.

Метою дослідження $\epsilon$ аналіз досвіду впровадження форм едьютейнменту на уроках інформатики у закладах загальної середньої освіти Кременчука. Мета реалізується через такі завдання: провести опитування серед вчителів інформатики кременчуцьких 33 СО стосовно використання у навчальному процесі найбільш поширених у світовій педагогічній практиці форм едьютейнменту; узагальнити результати опитування; виявити найбільш популярні форми едьютейнменту.

\section{МЕТОДИ ДОСЛІДЖЕННЯ}

Для розв'язання поставлених завдань та досягнення мети дослідження використано комплекс методів, серед яких основними є опитування (для виявлення форм едьютейнменту, які використовуються вчителями інформатики 33СО Кременчука), компаративний (для порівняння поширення ігрових практик у різних школах), а також методи математичної статистики (для кількісного та якісного аналізу емпіричних даних). Обраний методологічний інструментарій дозволив дослідити стан впровадження едьютейнменту на уроках інформатики у з3СО Кременчука.

\section{РЕЗУЛЬТАТИ ДОСЛІДЖЕННЯ}

Емпіричне дослідження використання форм едьютейнменту у навчанні інформатиці було здійснене за участі автора на базі кременчуцьких 33СО. У дослідженні були задіяні 36 учителів інформатики з 28 шкіл Кременчука.

Опитування здійснювалося у онлайн-режимі за допомогою Google форм. Учителі мали заповнити опитувальник, розроблений авторами дослідження. Автори свідомо зробили опитувальник стислим, включивши до нього лише три запитання. Це зумовлено тим, що аналіз впровадження форм едьютейнменту у з3СО Кременчука проводиться вперше, тобто цей моніторинг є лише першою сходинкою для подальших, більш детальних досліджень. Головною метою даного опитування було отримати загальні відомості про обізнаність кременчуцьких учителів інформатики про практики едьютейнменту і з'ясувати, які саме форми навчання через гру вони використовують.

Респондентам пропонувалося відповісти на три запитання: чи знайомі вони з практиками ігрового навчання (едьютейнменту); чи вважають вони їх корисними; які практики із запропонованих у опитувальнику вони використовують у навчальному процесі.

Результати опитування за першим пунктом (обізнаність учителів інформатики стосовно ігрових практик навчання) свідчать про те, що майже усі учителі інформатики кременчуцьких шкіл знайомі з практиками едьютейнменту. Лише два респонденти надали негативну відповідь. Результати опитування представлено на рис. 1. 
Відповіді респондентів на друге запитання опитувальника (думка про корисність едьютейнменту на уроках інформатики) говорять про те, що переважна більшість опитуваних (28 осіб) не лише знають про едьютейнмент, але й вважають ігрові практики корисними. Отже, можна зробити припущення про те, що усвідомлення педагогами доцільності та ефективності навчання через гру уможливлює упровадження форм едьютейнменту.

Результати опитування 36 респондентів

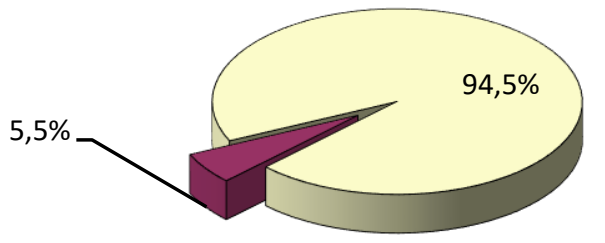

口Знайомі з едьютейнментом

口не знайомі

Рис. 1. Результати опитування учителів щодо ознайомлення з практиками ігрового навчання
Результати опитування 36 респондентів

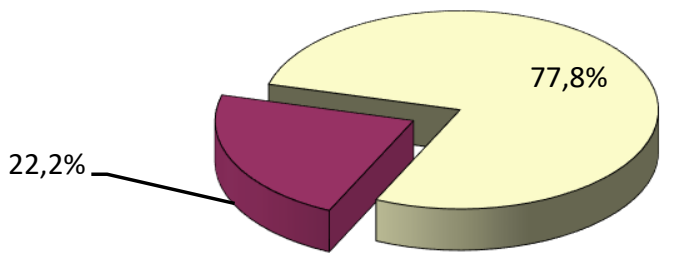

口Вважають корисними

Рис. 2. Результати опитування учителів щодо корисності практик ігрового навчання

Узагальнені результати аналізу використання форми едьютейнменту у навчанні інформатиці у закладах загальної середньої освіти Кременчука наведено у табл. 1.

Таблиця 1

Форми едьютейнменту на уроках інформатики

\begin{tabular}{|l|c|c|c|}
\hline \multirow{2}{*}{ 33СО } & \multicolumn{3}{|c|}{ Форми едьютейнменту } \\
\cline { 2 - 4 } & $\begin{array}{c}\text { Візуалізація } \\
\text { навчального } \\
\text { матеріалу }\end{array}$ & Змагання & Вебквест \\
\hline 33СО №1 & + & + & - \\
\hline 33СО №2 & + & + & - \\
\hline 33СО №3 & + & + & - \\
\hline 33СО №4 & + & + & + \\
\hline 33СО №5 & + & + & - \\
\hline 33СО №6 & + & + & + \\
\hline 33СО №7 & + & + & - \\
\hline 33СО №8 & + & - & - \\
\hline 33СО №9 & + & + & - \\
\hline 33СО №10 & + & + & - \\
\hline 33СО №11 & + & + & + \\
\hline 33СО №12 & + & + & - \\
\hline 33СО №15 & + & + & - \\
\hline 33СО №16 & + & + & - \\
\hline 33СО №17 & + & + & + \\
\hline 33СО №18 & + & + & - \\
\hline 33СО №19 & + & + & - \\
\hline 33СО №20 & + & + & - \\
\hline 33СО №22 & + & + & - \\
\hline 33СО №23 & + & + & - \\
\hline 33СО №24 & + & - & - \\
\hline 33СО №25 & + & + & + \\
\hline 33СО №26 & + & + & - \\
\hline 33СО №27 & + & - & - \\
\hline 33СО №28 & + & + & - \\
\hline 33СО №29 & + & + & + \\
\hline 33СО №30 & + & + & + \\
\hline 33СО №31 & + & + & + \\
\hline & & & + \\
\hline
\end{tabular}

Аналіз результатів опитування стосовно упровадження конкретних форм едьютейнменту у навчання інформатики показав, що найбільш поширеною формою $є$ візуалізація навчального матеріалу за допомогою мультимедіа. В усіх досліджуваних закладах освіти уроки інформатики проводяться з використанням візуалізації. Форми використання візуалізації на уроках інформатики є різноманітними - це може бути анімована графіка, тематичні відеоматеріали, презентації PowerPoint (статичні або анімовані) тощо. Потенціал візуалізації реалізується у межах мотиваційного компонента в процесі навчання інформатики за допомогою реалізації віртуальних експериментів для проведення 
спостережень, експериментів, вимірювань, побудови зображень (зокрема, анімованих), графіків, їх перетворень, вивчення моделей, які виявляють нові для учнів факти і властивості.

Навчання через змагання реалізується у 26 з 28 освітніх закладів. Учителям інформатики варто звернути увагу на перспективність цього різновиду едьютейнменту. Дидактичну цінність проведення спільної комп'ютерної гри чи змагання підкреслює Т. Барболіна, автор посібника з методики викладання шкільної інформатики (Барболіна, 2007, с. 116).

Вебквест задіяний на уроках інформатики у шести кременчуцьких школах. Варто зазначити, що разом усі запропоновані у опитувальнику форми ігрового навчання використовуються теж у цих шести закладах освіти. Необхідно зауважити, що ці заклади освіти є провідними кременчуцькими школами, які вибороли право мати статус ліцею, тобто профільної школи.

\section{ОБГОВОРЕННЯ}

Узагальнюючи методичні підходи до вивчення інформатики у загальній середній школі Л. Семко і Н. Самойленко основними ігровими практиками, які використовуються на уроках інформатики, називають завдання, що побудовані на принципі змагання (конкурси, вікторини, завдання на швидкість виконання або креативність тощо), вебквести і візуалізацію навчального матеріалу (Семко, Самойленко, 2015). Важливість використання засобів комп'ютерної візуалізації у шкільному навчанні підкреслюють Д. Безуглий (Безуглий, 2015), О. Семеніхіна та А. Юрченко (Семеніхіна, Юрченко, 2017). Уміння візуалізувати навчальний матеріал засобами мультимедіа кваліфікується вченими як фахова компетентність сучасного вчителя (Семеніхіна, Юрченко, 2014). Зарубіжні науковці теж вважають візуалізацію за допомогою мультимеліа основною формою едьютейнменту (Mukherjee, 2018; Nicholls, Fee, Budde-Sung, 2014). Указані наукові розвідки стали підґрунтям складання опитувальника для емпіричного дослідження.

Проведене емпіричне дослідження, яке $€$ початком постійного моніторингу стану впровадження форм едьютейнменту у навчання інформатики в кременчуцькій основній школі, свідчить про те, що лише окремі заклади загальної середньої освіти використовують таку форму навчання, як вебквест.

Сутність цієї ігрової форми полягає в тому, що частина інформації надається учителем, іншу учні знаходять, користуючись власними знаннями та пошуковими системами. Виконуючи завдання вебквесту, учень має переходити за гіперпосиланнями. У процесі вебквесту учень навчається не лише орієнтації в інформації, але й виконанню самостійного проєкту, адже він збагачує отриману з мережі інформацію власними думками, спостереженнями та висновками.

Вебквест $€$ однією з форм проблемного навчання і водночас проєктної роботи учнів. Це сучасна Інтернеттехнологія, яка дозволяє проводити дослідницьку, пошукову діяльність. Він надає можливість організувати самостійну проєкту діяльність учнів за будь-якою темою. У цьому аспекті важливо зазначити, що вебквест доцільно використовувати на інтегрованих уроках інформатики та інших предметів.

Технологія вебквесту сприяє виробленню компетентностей пошуку інформації, узагальнення, порівняння, аналізу, інтерпретації та оцінки, тобто критичного мислення. Корисною вона $€$ також у аспекті формування інформаційної культури учнів, підвищення медіа грамотності і загального розширення кругозору.

Вебквест має безліч різновидів і модифікацій. За кількістю учасників він може бути індивідуальним і командним. За часом - коротко- і довготривалим (навіть розрахованим на весь навчальний рік).

У процесі роботи вдосконалюються навички роботи на комп'ютері, вміння працювати самостійно і у команді, планувати спільну діяльність, вибудовувати стратегію і прогнозувати результат. Учні навчаються розв'язувати проблемну задачу декількома шляхами, обираючи оптимальний. Робота у групі навчає взаємодопомозі, стимулює вміння аргументувати власні дії, комунікувати в онлайн і офлайн форматах.

Квест, в основі якого є робота над гіперпосиланнями, дозволяє регулювати обсяг навчального матеріалу, інтенсивність і графік навчання, що стає підґрунтям для побудови індивідуальної траєкторії навчання.

Окрім вже описаних форм едьютейнменту у навчанні інформатики, ігрові практики можуть бути впроваджені на етапі оцінювання. Так, Л. Семко та Н. Самойленко пропонують власні електронні картки досягнень, які учні заповнюють самостійно у процесі виконання вправ. За успішне виконання завдань учень отримує не оцінки чи бали, а відзнаки, трофеї, що відображає одну з тенденцій, яка називається цифровими значками, які служать для візуалізації здобутих знань і навичок (Семко, Самойленко, 2015, с. 8). Роль використання різноманітних семіотичних ресурсів у едьютейнменті акцентує також К. Даніельсон (Danielsson, 2016). Організоване у такому ігровому форматі оцінювання сприяє підвищенню мотивації навчання, а також знижує риски невротизації учнів, яка часто є причиною зниження інтересу до навчання.

На основі проведеного емпіричного дослідження впровадження ігрових практик у навчання інформатики у кременчуцьких школах розроблено низку рекомендацій для вчителів:

- необхідно на міському рівні виявляти та узагальнювати інноваційні ігрові педагогічні практики (це може бути реалізовано у вигляді методичних семінарів, вебінарів, конференцій, форумів, мастер-класів тощо);

- варто створити креативний освітньо-культурний простір для моделювання і розробки нових ігрових форм навчання (наприклад, на базі Кременчуцького міського науково-методичного центру (КМНМЦ));

- слід організувати популяризацію і поширення інноваційних ігрових технологій, а також методів едьютейнменту серед вчителів інформатики шляхом ознайомлення з передовим досвідом провідних закладів освіти (зокрема, ознайомлення широкого освітянського загалу з технологією проведення вебквестів, а також оприлюднення інформації на сайті КМНМЦ і, можливо, у вигляді друкованих методичних рекомендацій);

- поширенню передових освітніх практик сприятиме організація щорічного фестивалю едьютейнменту для освітян міста.

На нашу думку, виконання цих рекомендацій підвищить рівень викладання і навчання інформатики у кременчуцьких закладах загальної середньої освіти. 


\section{ВИСНОВКИ ТА ПЕРСПЕКТИВИ ПОДАЛЬШОГО ДОСЛІДЖЕННЯ}

Упровадження нових ігрових і педагогічних технологій у практику освітніх установ, зокрема, закладів загальної середньої освіти, є важливим завданням української педагогіки. Едьютейнмент, який поєднує навчання та гру, дозволяє ненав'язливо подати теоретичний матеріал у цікавій і доступній для учнів формі. Він $є$ особливим типом навчання, що ґрунтується на рекреації і формуванні первинного інтересу до предмета з отриманням задоволення від процесу навчання і стійким інтересом до процесу навчання.

Едьютейнмент нерозривно пов'язаний з інформаційними технологіями. Саме тому він надає унікальний інструментарій для навчання інформатики, яка $є$ наукою про комп'ютер і віртуальне середовище.

Основними формами едьютейнменту $є$ візуалізація навчального матеріалу, організація навчання через змагання і вебквест. Останній $€$ найскладнішою, але водночас найефективнішою технологією, яка дозволяє навчитися самостійному набуттю знань з використанням мультимедіа. Теоретичні знання і практичні навички з використання вебквестів у процесі підготовки і проведення уроків з інформатики передбачають знання програмних і комп'ютерних засобів, методик і дидактичних прийомів їх застосування.

Емпіричне дослідження досвіду впровадження форм едьютейнменту у навчання інформатики в школах Кременчука засвідчило обізнаність вчителів у ігрових практиках, розуміння ї корисності та широке використання візуалізації та навчання через змагання. Водночас вебквест реалізований лише у шести школах, що говорить про необхідність популяризації цієї технології.

Імплементація едьютейнменту у навчання інформатики здатна значно підвищити пізнавальну активність та мотивацію учнів до вивчення предмету. Крім того, ігрові практики сприятимуть зменшенню психологічної напруженості, пов'язаної з перенавантаженням, збільшенням часу перебування дитини за комп'ютером чи іншими гаджетами, страхом перед оцінюванням тощо.

Результати проведеного емпіричного дослідження можуть стати основою подальшого наукового моніторингу поширення практик едьютейнменту в українських закладах загальної середньої освіти.

\section{Список використаних джерел}

1. Барболіна Т. М. Шкільний курс інформатики та методика його викладання: Навчальний посіб. Полтава: Полтав. держ. пед. університет ім. В.Г. Короленка, 2007. Ч. 1. Загальна методика. 124 с.

2. Безуглий Д. С. Візуалізація як сучасна стратегія навчання. Фізико-математична освіта. 2015. № 1 (7). С. $146-149$.

3. Крутій К. Едьютейнмент: навчання як розвага. Дошкільне виховання. 2017. №1. URL: http://ukrdeti.com/ edyutejnmentnavchannya-yak-rozvaga/.

4. Семеніхіна О., Юрченко А. Професійна готовність використовувати засоби комп'ютерної візуалізації у роботі вчителя: теоретичний аспект. Наукові записки. Серія: Проблеми методики фізико-математичної і технологічної освіти. Кропивницький: РВВ КДПУ ім. В. Винниченка, 2017. Вип. 11. Ч. 4. С. 43-46.

5. Семеніхіна О., Юрченко А. Уміння візуалізувати навчальний матеріал засобами мультимедіа як фахова компетентність учителя. Науковий вісник Ужгородського національного університету: Серія "Педагогіка. Сочіальна робота». Ужгород: Видавництво УжНУ «Говерла». 2014. Вип. 33. С. 176-179.

6. Семко Л., Самойленко Н. Методичні підходи до вивчення інформатики в основній школі. Наукові записки. Серія: Проблеми методики фізико-математичної і технологічної освіти. Вип. 7. Ч. 2. Кіровоград, 2015. С. 76-82.

7. Aksakal N. Theoretical View to the Approach of the Edutainment. Social and Behavioral Sciences. 2015. Vol. 186. pp. 12321239.

8. Corona F., Cozzarelli C., Palumbo C., Sibilio M. Information technology and edutainment: Education and Entertainment in the age of interactivity. International Journal of Digital Literacy and Digital Competence. 2013. Vol. 4. pp. 12-18.

9. Corona F., Perrotta F., Polcini E. T., Cozzarelli C. The new frontiers of edutainment: The development of an educational and socio-cultural phenomenon over time of globalization. Journal of Social Science. 2011. Vol. 7. pp. 408-411.

10. Danielsson K. Modes and meaning in the classroom - The role of different semiotic resources to convey meaning in science classrooms. Linguistics and Education. 2016. Vol. 35. pp. 88-99.

11. Fee A., Budde-Sung A. E. K. Using video effectively in diverse classes: What students want. Journal of Management Education. 2014. Vol. 38. pp. 843-874.

12. Mukherjee S. Role of multimedia in education. Edelweiss Applied Science and Technology. 2018. Vol. 2. Iss. 1. pp. $245-247$.

13. Němec J., Trna J. Edutainment or Entertainment Education Possibilities of Didactic Games in Science Education. In Němec J. (ed.) The evolution of children play - 24. ICCP Word Play Conference. Brno: Pedagogická fakulta, Masarykova univerzita, Brno, 2007. URL: http://www.iccpplay.org/documents/brno/nemec_trna.pdf

14. Nicholls M. Digital Visualisation in Classics Teaching and Beyond. Journal of Classics Teaching. 2016. Vol. 17. Iss. 33. pp. 2730.

15. Okan Z. Edutainment: Is Learning At Risk? British Journal of Educational Technology. 2003. Vol. 34. Iss. 3. pp. 255-264. URL: https://doi.org/10.1111/1467-8535.00325

16. Zeedyk M. S., Wallace L. Tackling children's road safety through edutainment: an evaluation of effectiveness. Health Education Research. 2003. Vol. 18. Iss. 4. pp. 493-505. URL: https://doi.org/10.1093/her/cyf033

\section{References}

1. Barbolina, T. M. Shkilnyi kurs informatyky ta metodyka yoho vykladannia: Navchalnyi posibnyk [School course of computer science and methods of its teaching: Textbook]. Poltava: Poltava V. G. Korolenko state ped. university, 2007. Part 1. General methods. 124 p. [In Ukranian].

2. Bezugly, D. S. (2015). Vizualizatsiia yak suchasna stratehiia navchannia [Visualization as a modern learning strategy]. Physical and mathematical education, 1 (7), 146-149. [In Ukranian]. 
3. Krutiy, K. (2017). Ediuteinment: navchannia yak rozvaha [Education: learning as entertainment]. Preschool education, 1. http://ukrdeti.com/ edyutejnment-navchannya-yak-rozvaga, Last accessed: 2021/03/04 [In Ukranian].

4. Semenikhina, O., Yurchenko, A. (2017). Profesiina hotovnist vykorystovuvaty zasoby kompiuternoi vizualizatsii u roboti vchytelia: teoretychnyi aspect [Professional readiness to use computer visualization in the work of a teacher: a theoretical aspect]. Proceedings. Series: Problems of methods of physical-mathematical and technological education. Kropyvnytskyi: RVV KDPU, 11 (4), 43-46. [In Ukranian].

5. Semenikhina, O., Yurchenko, A. (2014). Uminnia vizualizuvaty navchalnyi material zasobamy multymedia yak fakhova kompetentnist uchytelia [Ability to visualize educational material by means of multimedia as a professional competence of the teacher]. Scientific Bulletin of Uzhhorod National University: Series "Pedagogy. Social work". Uzhhorod: Uzhhorod National University Publishing House "Hoverla", 33, 176-179. [In Ukranian].

6. Semko, L., Samoilenko, N. (2015). Metodychni pidkhody do vyvchennia informatyky v osnovnii shkoli [Methodical approaches to the study of computer science in primary school]. Proceedings. Series: Problems of methods of physical-mathematical and technological education, 7(2). Kirovograd, 76-82. [In Ukranian].

7. Aksakal, N. (2015). Theoretical View to the Approach of the Edutainment. Social and Behavioral Sciences, 186, 1232-1239.

8. Corona, F., Cozzarelli C., Palumbo C., Sibilio M. (2013). Information technology and edutainment: Education and Entertainment in the age of interactivity. International Journal of Digital Literacy and Digital Competence, 4, 12-18.

9. Corona, F., Perrotta, F., Polcini, E. T., Cozzarelli, C. (2011). The new frontiers of edutainment: The development of an educational and socio-cultural phenomenon over time of globalization. Journal of Social Science, 7, 408-411.

10. Danielsson, K. (2016). Modes and meaning in the classroom - The role of different semiotic resources to convey meaning in science classrooms. Linguistics and Education, 35, 88-99.

11. Fee, A., Budde-Sung, A. E. K. (2014). Using video effectively in diverse classes: What students want. Journal of Management Education,38, 843-874.

12. Mukherjee, S. (2018). Role of multimedia in education. Edelweiss Applied Science and Technology, 2 (1), $245-247$.

13. Němec, J., Trna, J. (2007). Edutainment or Entertainment Education Possibilities of Didactic Games in Science Education. In Němec J. (ed.) The evolution of children play - 24. ICCP Word Play Conference. Brno: Pedagogická fakulta, Masarykova univerzita, Brno, 2007. http://www.iccpplay.org/documents/brno/nemec_trna.pdf Last accessed: 2021/03/12.

14. Nicholls, M. (2016). Digital Visualisation in Classics Teaching and Beyond. Journal of Classics Teaching, 17 (33), 27-30.

15. Okan, Z. Edutainment: Is Learning At Risk? (2003). British Journal of Educational Technology, 34 (3), 255264. https://doi.org/10.1111/1467-8535.00325 Last accessed: 2021/04/08.

16. Zeedyk, M. S., Wallace, L. (2003). Tackling children's road safety through edutainment: an evaluation of effectiveness. Health Education Research, 18 (4), 493-505. https://doi.org/10.1093/her/cyf033 Last accessed: 2021/04/02.

\section{EDUTAINMENT IN COMPUTER SCIENCE LESSONS: EXPERIENCE OF IMPLEMENTATION IN KREMENCHUK SCHOOLS Olena Hrytsiuk, Varvara Chernenko, Larysa Maksymova \\ Kremenchuk Mykhailo Ostrohradskyi National University, Ukraine}

Abstract.

Formulation of the problem. The paper deals with the results of the empirical study of the state of implementation of edutainment, i.e. learning through play, in secondary schools of Kremenchuk. The purpose of the study is to analyze the experience of implementing elements of edutainment in computer science lessons.

Materials and methods. To solve the tasks and achieve the goal of the study, a set of methods was used, the main of which are surveys (to identify elements of edutainment used by Kremenchuk teachers of computer science), comparative (to compare the spread of gaming practices in different schools) and mathematical statistics (for quantitative and qualitative analysis of empirical data). The survey was conducted online using Google Forms.

Results. Respondents were asked to answer three questions: are they familiar with game learning practices; do they find them useful; which of the practices proposed in the questionnaire they use in the educational process. Analysis of the results of the survey on the introduction of specific elements of edutainment in the teaching of computer science showed that the most common form is the visualization of educational material using multimedia. Training through competitions is implemented in 12 out of 28 educational institutions. Webquest is involved in computer science lessons in six schools. It is worth noting that together all the elements of game learning proposed in the questionnaire are also used in these six educational institutions. It should be noted that these six educational institutions are the leading Kremenchuk secondary schools. The analysis of the introduction of elements of edutainment in computer science lessons in Kremenchuk secondary schools is carried out for the first time, i.e. this monitoring is only the first step for further, more detailed research. The article contains a set of practical recommendations for the wider introduction of various forms of edutainment in computer science lessons in Kremenchuk schools; in particular, this applies to such a popular form today as a webquest. Teachers' awareness of the expediency and effectiveness of learning through play allows for the introduction of elements of edutainment.

Conclusions. The survey showed that in most educational institutions there are some restrictions on the use of specific forms of edutainment: if the visualization of educational material is used in all schools, then competitive forms of learning and especially web quests need the attention of computer science teachers. The study proves the expediency of a wider introduction of the webquest as a tool to increase the cognitive activity of students, as well as their motivation to study computer science.

Keywords: edutainment, game teaching practices, computer science, Kremenchuk secondary schools, visualization of educational material, competitions, webquest. 